\title{
A SZUBSZIDIARITÁS ELVÉNEK JELENTÉSE ÉS MEGJELENÉSE AZ EURÓPAI INTEGRÁCIÓS, VALAMINT A MAGYAR TAGÁLLAMI JOGALKOTÁSBAN
}

Interpretation of Subsidiarity and its Existence in the Legislation of the European Integration and its Hungarian Member State

\section{Szőke-Kis Bernadett ${ }^{1}$}

\begin{abstract}
Absztrakt: A szubszidiaritás, mint eszme már az 1850-es években megjelent Abraham Lincoln politikájában az akkori Amerikai Egyesült Államokban azt hirdette, hogy az államnak kötelessége ellátni azon feladatokat, amelyek beteljesítésére egy közösség nem képes, ugyanakkor távol kell tartania magát azoktól a területektől, ahol a közösség önálló cselekvésre alkalmas. Ezen eszme a történelem előrehaladtával nemcsak a politika, hanem további tudományterületeken saját, önálló értelmezést nyert, míg végül a XX. században az európai integráció bővülő és egyre inkább kiterjedő mûködésébe fészkelte magát - ezáltal tagállamként a magyarországi jogalkotásra és jogrendszerre is kifejtve a hatását. A fogalomtárak mellett főként tudományos folyóiratokban megjelent szaktanulmányok, valamint integrációs szerződések és egyéb szervezeti jogi aktusok segítették munkámat, aminek célja röviden végig-vezetni, hogyan vált egy általános, többféle értelmezésben létező eszme egy regionális nemzetközi szervezet alapelvévé, továbbá hogyan jelenik meg ezáltal az Európai Unió tagállamaként hazánk jogi körülményeiben is.
\end{abstract}

Kulcsszavak: Európai Unió, szubszidiaritás, integrációs jogalkotás, tagállami hatás

\footnotetext{
1 Szőke-Kis Bernadett a Szegedi Tudományegyetem Állam- és Jogtudományi Doktori Iskola, Nemzetközi és Regionális Tanulmányok Intézet harmadéves doktorandusz hallgatója. Kutatási területe Az állam szerepe a nemzetközi viszonyokban - azon belül a posztszovjet térség államtöredékeire koncentrál. Elérhetőség: bernadett.szokekis@irsi.uszeged.hu

A szerző további munkásságát lásd a Magyar Tudományos Művek Tára oldalán: https: $/ / \mathrm{m} 2 . \mathrm{mtmt}$. hu $/$ gui2 $/$ ?type $=$ authors\&mode=browse\&sel $=10064922$
} 
Abstract: The precept of subsidiarity dates back to the 1850'ies as it was an important part of the political perception of Abraham Lincoln himself - he believed that it was an obligation of a state to perform tasks that could not be done or reached by the society, but at the same time the state should not be acting in cases where the people themselves are capable of doing so. As history progressed, subsidiarity became an idea in other fields of science outside of the realm of politics as well, eventually turning into one of the main principles of a forming and growing integration in the region of Europe. With that, the theory of subsidiarity not only became a part of the working ways of an international organization but also found its way into the legal system of its member states. With the help of different interpretation of the same principle, academical studies, and mainly treaties and further legal documents of the European Union, this study aims to follow the development of the idea of subsidiarity and examine its existence in the regional integration of Europe as well as in one of its member states, in Hungary.

Keywords: European Union, subsidiarity, integrational legislation, effect on member states

\section{BEVEZETÉS}

A szubszidiaritás szigorú fogalmi megközelítés szerint „kisegítő, mellérendelt minőség, vagy állapot intézménye”, illetve „,azon elv, miszerint a döntések meghozatalára a lehető legalacsonyabb szinten, vagy a hatásukat leginkább kifejtő területen szükséges, így például inkább lokálisan, mint országos szinten". 3

A szubszidiaritás, mint elv feldolgozásra került a vallás-, de akár az orvostudomány értelmezésében is, mielőtt döntéshozatali folyamatot meghatározó elvként megjelent az európai integrációs politikában. A keresztény megközelítés szerint a szubszidiaritás nem más, mint a kisegítés elve. Az alacsonyabb szint kerül előtérbe a magasabbakkal szemben. Ennek értelmében az egyén és a család kerül a társadalom, míg a település és a régió az országos, vagy nemzetközi szint előterébe. ${ }^{4}$ Maga a fogalom XI. Piusz pápa munkásságában, 1931-ben a Quadragesimo Anno címú művében jelenik

2 MERriAM - WebSTER DiCTIONARY, 2018.

${ }^{3}$ CAMBridge DiCTIONARY, 2018.

4 Magyar Katolikus Lexikon, 1993. 
meg a vallástudomány területén először. Az itt leírtakban az egyén elsődlegességét fogalmazza meg az államhatalommal szemben. A szubszidiaritás elve megjelenik továbbá XIII. János pápa Mater et Magistra címú munkájában is, aki a szubszidiaritás megvalósulását az állam fellépésének korlátozásában látta megvalósulni. ${ }^{5}$ 1991-ben, II. János Pál pápa Centesimus Annus címú múvében a szubszidiaritás fogalmát már a jóléti állammal kapcsolatban értelmezi, ekkor kezd el a vallástudományi értelmezés közeledni az elv mai, politikai felfogásához. 1994-ben George Higgins püspök e felfogáshoz hasonlóan, már az állam a társadalommal szembeni háttérbe szorítását helyezi kutatásai középpontjába. ${ }^{6}$

Mielőtt kitérnék a szubszidiaritás elvének európai integráción belüli fejlődésére, a fogalom vizsgálata során akár kitekintésként is, de szót kell ejteni az elv egészségpolitikai értelmezéséről. Ennek keretein belül a szubszidiaritás elve nem más, mint az öngondoskodás. Az egészségügyben szorosan a szolidaritás elvéhez kapcsolódóan alakult ki a szubszidiaritás felfogása, miszerint az egyén számára szükséges a segítség biztosítása, de a felsőbb szintek szükségtelen beavatkozása nélkül. A közösség köteles gondoskodni az egyénről, de ez a közösségi fellépés nem váltja fel az egyén önálló aktivitását és öngondoskodását. Az egyén biztonsága abban rejlik, hogy ha önállóan nem képes adott probléma kezelésére, segítséget kérhet és kaphat az állami ellátó rendszertől. ${ }^{7}$

\section{A SZUBSZIDIARITÁS ELVÉNEK KIALAKULÁSA AZ EURÓPAI INTEGRÁCIÓ FEJLŐDÉSE SORÁN}

A szubszidiaritás fogalmi áttekintése során megállapíthatóvá vált, hogy bármely tudományterületen jelenjen is meg, az elv az alacsonyabb szintek önállóságának lehetőségét hordozza magában. A vizsgálat következő lépéseként a szubszidiaritás elvének kialakulását és térnyerését tekintem át az európai integráció fejlődése során.

A szubszidiaritás elve az egyháztudomány területérôl került át az európai szintű politikába. Az integrációs politikában napjainkban az elv már nemcsak a megsegítés kapcsán van jelen, hanem egyfajta vertikális

\footnotetext{
${ }^{5}$ FARKAS, 2014. 66.o.

${ }^{6}$ BOSNICH, 2010.

${ }^{7}$ EgÉSZSÉGTUdOMÁNYI FOGALOMTÁR, 2018.
} 
hatalommegosztás szerint a Közösség és a tagállamok viszonyát is rendezi, hangsúllyal az integráció belsô szerkezetén és a hatáskörök felosztásán. ${ }^{8}$

Kialakulását tekintve az integráció fejlődése során először 1971-ben jelenik meg a közösségi politikában, amikor Ralf Dahrendorf Európai Bizottsági tag megfogalmazza a „hasznos funkcionalitás” elvét. Az 1974-es kilencek párizsi csúcstalálkozója által életre hívott 1995-ös Tindemans jelentés a bővítés lehetőségét vizsgálva ez alapján fogalmazza meg az „ember közelibb Európa” eszméjét, ahol a szubszidiaritás a hatáskörök megosztása kapcsán kerül előtérbe.

A szubszidiaritás elve az európai integráció fejlődése során szerződéses szinten először 1987-ben jelenik meg az Egységes Európai Okmányban, a szerződés 130r cikkének 4. bekezdésében. Ekkor még csupán a környezetvédelemmel kapcsolatos fellépés koordinálására irányul. A 130r cikk 4. bekezdése kimondja, hogy a megfogalmazott célok elérése érdekében mérlegelni kell, hogy a közösségi vagy tagállami fellépéssel lehet-e hatékonyabban elérni a kitűzött célokat. ${ }^{10}$

Ezt követően az integrációs jogalkotásban 1992-ben a Maastrichti Szerződés rendelkezéseiben találkozhatunk a szubszidiaritás elvével. A szerződés Preambulumának A cikk 2. bekezdésében a Közösség kimondja egy eddigieknél szorosabb együttmúködés kialakítását, ahol a döntéshozatal az európai polgárokhoz legközelebbi szinten kell történjen. Ugyanezen dokumentum Preambulumának B cikk 2. bekezdése kimondja, hogy az integráció múködése során nem csak a szerződésekbe foglaltakat, de a szuverenitás elvét is köteles tiszteletben tartani. A Maastrichti Szerződés 3b cikkének 2. bekezdése továbbá rendelkezik a nem kizárólagos jogkörökről. Az integráció a szubszidiaritás elve alapján mérlegelni köteles a közösségi szintű fellépést a nem kizárólag közösségi hatáskör alá eső kérdések során. Az Unió akkor léphet fel említett esetekben, ha a tagállami fellépés nem bírna kellő hatékonysággal, akkor is kizárólag a szükséges mértékben. ${ }^{11}$

$\mathrm{Az}$ 1992-ben Edinburgh-ban lezajló Európai Tanács ülésének kiegészítő rendelkezései a Maastrichti Szerződésbe foglaltak megvalósítása érdekében a dokumentum A részének 5-6. pontjaiban egy intézményközi megállapodás kidolgozását helyezi előtérbe. Ennek célja, hogy az Európai Tanács, az Európai Bizottság és az Európai Parlament tevékenységét

\footnotetext{
8 SCHILLING, 1995.

${ }^{9}$ VARGA, 2016.

${ }^{10}$ EgYSÉGES EURÓPAI OKMÁNY, 1986.

11 AZ EurópAi UNIÓRÓL SZÓLÓ SZERZŐDÉS (MAASTRICHTI SZERZŐDÉS), 1992.
} 
koordinálják z 1992-es szerződés 3b cikkébe foglaltak végrehajtására (ez az Intézményközi Megállapodás 1993. október 25-én lépett életbe). A megállapodás mellett az Európai Bizottságnak kiemelt feladataként fogalmazzák meg a már létező jogi szabályozások vizsgálatát a szubszidiaritás elvének fényében. ${ }^{12}$

Az 1997-es Amszterdami Szerződés egy három oldalas jegyzőkönyvet tartalmaz a „szubszidiaritás és az arányosság elveinek alkalmazásáról”. A 13 bekezdésből álló jegyzőkönyv rendelkezik többet között az arányosság elvérôl - ennek értelmében az intézmények az elérendő cél elérése érdekében szükséges eszközökkel léphetnek fel. A Szerződés jegyzőkönyvébe foglalták ezen felül például az intézményi egyensúlyt a Bíróság teljes semlegessége mellett, a közösségi hatáskörök túllépésének feltételeit, kvalitatív és kvantitatív indikátorokat, vagy a végrehajtás egyszerűségének, de hatékonyságának szükségességét. ${ }^{13}$

Az utolsó a szubszidiaritás elvérôl rendelkező szerződéses szabályozás a 2007-ben ellenjegyzett Lisszaboni Szerződés jegyzőkönyve a szubszidiaritás és az arányosság elvének alkalmazásáról. Ennek rendelkezése nem csak megerősítik az Amszterdami Szerződés érintett elemeit, de növelik a nemzeti parlamentek részvételi lehetőségeit a közösségi jogalkotásban. A Lisszaboni Szerződés 2. jegyzőkönyvének 7. cikke kötelezi az Európai Bizottságot a jogszabályi tervezetek megküldésére, nem csupán az Európai Tanács és az Európai Parlament, de a nemzeti parlamentek részére is, amelyek fellebbezéssel élhetnek. ${ }^{14}$

A szubszidiaritás elvének értelmezése és annak változása mellett a folyamat gyakorlati megvalósulásáról részletesen a következő fejezetben, a Magyarországot érintő esetek áttekintésével értekezem.

\section{SZUBSZIDIARITÁS AZ EURÓPAI INTEGRÁCIÓ GYAKORLATÁBAN - A NEMZETI PARLAMENTEK ÁLTAL GYAKOROLT ELLENŐRZÉS MAGYARORSZÁG PÉLDÁJÁN}

A bemutatott fejlődési folyamat eredményeképpen mára a szubszidiaritás az Európai Unió múködésének alapelvévé vált. A gyakor-

\footnotetext{
12 European COUNCIL IN Edinburgh, 1992.

13 AMSZTERDAMI SZERZŐDÉS, 1997.

${ }^{14}$ LISSZABONI SZERZŐDÉS, 2008.
} 
latban egyrészt a jogalkotási hatáskörök, másrészt a döntéshozatali folyamatok a polgárokhoz történő közelítése során valósul meg.

A hatáskörök kérdéséről a Maastrichti Szerződés 5. cikke rendelkezik. Amellett, hogy elválasztják a közösségi és tagállami hatásköröket, a korábban már leírt hatékonyság alapján azok átruházását is kezeli - kizárólag abban az esetben, ha a közösségi szinten hatékonyabban lehet cselekedni adott kérdésben, és csupán szükséges mértékben teszi lehetôvé. ${ }^{15}$

A jogalkotás során a tagállamok pozíciójának erősödése a gyakorlatban 1997., az Amszterdami Szerződés óta zajlik. A Szerződés úítása a jogalkotási folyamat során, hogy az Európai Bizottság jogalkotási javaslat kidolgozása előtt köteles adott területet érintő zöld könyv kiadására. Ennek eredményeképpen a Bizottság a jogalkotási aktus előtt képes tájékozódni a tagállami állásfoglalásokról adott kérdés kapcsán. ${ }^{16}$ A 2007 ben aláírt Lisszaboni Szerződés további két újitásának eredményeképpen tovább nő a szubszidiaritás szerepe az uniós jogalkotási folyamat során. Egyrészt, a Szerződés jogot biztosít a Régiók Bizottsága számára bármely jogalkotási tervezet megvétózására, ${ }^{17}$ amennyiben az nem felel meg a szubszidiaritás elvének. Másrészt, a nemzeti parlamentek szintén képességre tesznek szert egy-egy jogalkotási tervezettel szembeni fellépésre. ${ }^{18}$

A nemzeti parlamentek felé a Lisszaboni Szerződésbe foglaltak alapján kötelező továbbítani fehér és zöld könyveket, közleményeket, az Európai Tanács ülésének napirendjét, a Számvevőszék éves jelentését és a Bizottság éves jelentését, emellett pedig a jogalkotási javaslatokat is. A Szerződés második jegyzőkönyvének A szubszidiaritás és az arányosság elvének alkalmazásáról 7. cikke alapján a megküldött javaslatokkal kapcsolatban a nemzeti parlamentek nyolc héten belül indokolt véleményt fogalmazhatnak meg. ${ }^{19}$ Amennyiben egy adott javaslat kapcsán az egyenként két szavazattal rendelkező tagállamok egyharmada fogalmaz meg indokolt véleményt, a jogalkotónak mérlegelnie kell, hogy fenntartja, módosítja vagy semmissé teszi javaslatát (a biztonságot és szabadságot érintő kérdésekben ehhez a tagállamok egynegyedének állásfoglalása elegendő, a tagállamok felének indokolt véleményénél pedig kötelezően felülvizsgálandó adott tervezet). Az indokolt vélemények egyharmados szavazását nevezzük sárga

\footnotetext{
15 AZ EurópAi UNiÓRÓl SZÓLÓ SZERZŐDÉS (MAASTRICHTI SZERZŐDÉS), 1992.

16 EUR-LEX, 2015.

${ }^{17}$ EUR-LEX, 2018.

${ }^{18}$ EUR-LEX, 2015.

${ }^{19}$ EUROPEAN PARLIAMENT, 2020.
} 
lapos eljárásnak. Abban az esetben, ha a nemzeti tagállamok többsége állapítja meg a szubszidiaritás elvének megsértését narancssárga lapos eljárásról beszélünk. Előbbi 19, utóbbi 29 tagállamot jelent. ${ }^{20}$

Magyarországon az európai integrációval kapcsolatos ügyekért a parlament erre kinevezett Európai ügyek bizottsága felelős, az Országgyúlésről szóló 2012. évi XXXVI. törvény és az egyes házszabályi rendelkezésekről szóló 10/2014. (II. 24.) OGY határozat alapján. Magyarország már a Lisszaboni Szerződés újitásai előtt is részt vett az úgynevezett COSAC együttműködésben - a nemzeti parlamentekben mûködtetett európai ügyekért felelős bizottságok által és számukra szervezett konferenciákon 2004 és 2009 között. 2009 óta a Szerződés újitása és szabályai szerint az Országgyúlés összesen öt alkalommal fogalmazott meg indokolt véleményt az Európai Bizottság számára. ${ }^{21}$

Elsőként 2013. október 21-én, az Európai Ügyészség létrehozásáról szóló tanácsi rendelettervezettel szemben. A cél egy integrációs szintű hatóság létrehozása az uniót károsító bủnözők felkutatására. Mivel az uniós, főleg pénzügyileg károsító bủncselekményekről van szó, integrációs szintű fellépéssel lehetne leginkább fellépni velük szemben. ${ }^{22}$ Ez eddig tagállami hatáskörbe tartozott, nem meglepő tehát, hogy összesen 18 szavazat érkezett be a tervezet ellen. Az Európai Bizottság felülvizsgálta a javaslatot, azonban nem eszközöltek módosítást. ${ }^{23}$

A második, Magyarország által megfogalmazott indokolt vélemény 2015. november 3-i, az áthelyezési válságmechanizmus létrehozásáról, valamint az egy harmadik országbeli állampolgár vagy egy hontalan személy által a tagállamok egyikében benyújtott nemzetközi védelem iránti kérelem megvizsgálásáért felelős tagállam meghatározására vonatkozó feltételek és eljárási szabályok megállapításáról szóló parlamenti és tanácsi rendelet ellen. Az integrációs szintű migrációs stratégia részeként, főként Olaszország és Görögország érdekében, javaslat egy ideiglenes áthelyezési mechanizmus kidolgozására. Cél az erôteljes migrációs folyamatok kezelése, kizárólag szükséghelyzetben és szigorú feltételek mellett. ${ }^{24}$

\footnotetext{
${ }^{20}$ LISSZABONI SZERZŐDÉS, 2008.

21 OrSZÁGgYÜLÉs, 2020.

$22 \mathrm{COM} / 2013 / 0534$ javaslat

23 ORSZÁGGYƯLÉS, 2020.

${ }^{24} \mathrm{COM} / 2015 / 0450$ javaslat
} 
Mindössze hét szavazat az indokolt véleményeken keresztül, így nem került újradolgozásra uniós szerv elé a javaslat. ${ }^{25}$

2016. május 10 - a munkavállalók szolgáltatások nyújtása keretében történő kiküldetéséről szóló, 1996. december 16-i 96/71/EK európai parlamenti és tanácsi irányelv módosításáról szóló európai parlamenti és tanácsi irányelvtervezet ellen léptek fel a harmadik alkalommal. A munkavállalók, kifejezetten a szolgáltatást nyújtó dolgozókkal szembeni tisztességtelenségek csökkentését célzó javaslat került megfogalmazásra. A hangsúly a díjazások közelítésére kerül, cél a mélyebb és tisztességesebb piac. Kifejezetten koncentrál a fuvarozók munkakörülményeinek javítására. ${ }^{26}$

Nem kizárólagos hatáskörről van szó, 22 szavazat érkezett be ellene, így az Európai Bizottság felülvizsgálta a javaslatot. Végül változtatások nélkül fenntartották. ${ }^{27}$

A negyedik, 2016. június 13-i indokolt vélemény az egy harmadik országbeli állampolgár vagy egy hontalan személy által a tagállamok egyikében benyújtott nemzetközi védelem iránti kérelem megvizsgálásáért felelős tagállam meghatározására vonatkozó feltételek és eljárási szabályok megállapításáról szóló európai parlamenti és tanácsi rendelettervezet (átdolgozás) ellen irányult. Szintén a migrációs válság kapcsán megfogalmazott javaslat, a nemzetközi védelemre szorulók megsegítése a tervezet célja. Így például célkitűzés az embercsempészet visszaszorítása. Valószínű, hogy a bevándorlási folyamat hosszútávon fennáll, így közös befogadó rendszer kialakítása szükséges. Az integrációs szintű menekültügyi rendszer a felelősség megosztását célozza. ${ }^{28}$

Tíz szavazat érkezett a javaslat ellen, ami nem elég annak felülvizsgálatára. ${ }^{29}$

A tanulmány lezárásáig az utolsó, 2017. május 3-i indokolt vélemény a villamos energia belső piacáról szóló európai parlamenti és tanácsi rendelettervezet (átdolgozás) ellen léptek fel. A tervezet egy integrált energiapiac létrehozását helyezi előtérbe. Cél a megfizethetőség, és a megújuló energiaforrásokból fedezett energiaigény arányának növelése,

\footnotetext{
25 ORSZÁGGYÜLÉS, 2020.

${ }^{26} \mathrm{COM} / 2017 / 0647$ javaslat

27 ORSZÁGGYÜLÉS, 2020.

${ }^{28} \mathrm{COM} / 2016 / 0270$ javaslat

29 ORSZÁGGYÛLÉs, 2020.
} 
valamint az energiahatékonyság. ${ }^{30} 13$ szavazattal a javaslat nem került felülvizsgálásra. ${ }^{31}$

\section{KONKLÚZIÓ}

2009. december 1-jétől 2012 év végégig nem került sor a szubszidiaritás elve alapján benyújtott indokolt vélemények alapján jogszabály javaslat felülvizsgálatára. Ez nem jelenti azt, hogy egy tagállam sem fogalmazott meg indokolt véleményt, csupán a számuk nem érte el a meghatározott minimumot a javaslat Bizottság elé citálásához. Míg 2010ben az indokolt vélemények száma 34-volt, 2012-re ez 64-re nőtt. A tagállamok szerepvállalása tehát folyamatosan növekvő tendenciát mutat. A szubszidiaritás elvének gyakorlati megvalósulását mégis éri kritika. Egyes elképzelések szerint a hatékonyságot tovább növelhetnék, ha a tagállamok számára rendelkezésre álló időtartamot meghosszabbítanák a jelenlegi nyolchetes határidő helyett, illetve fontos megjegyezni azt is, hogy a nemzeti tagállamok együttmúködési folyamatai sem teljesen kiforrottak. ${ }^{32}$

A hatékonyság növelésének céljával a Junker-bizottság létrehozott egy munkacsoportot, aminek feladata a szubszidiaritás és arányosság erősítése a „kevesebbet, hatékonyabban” hívószavak értelmében. A munkacsoport 2018 júniusáig hét alkalommal ült össze, és a következő javaslatokat fogalmazta meg: ${ }^{33}$

- A korlátozott források hatékonyabb felhasználására van szükség a teljes integrációt érintő kihívások kezelésére, mint például a bevándorlás

- Hatékonyabb hozzájárulási forma kidolgozására van szükség a nemzeti parlamentek számára, hogy a politikaalakító folyamatokban erőteljesebben képviseltethessék magukat

- A hozzájárulási lehetőség jobb megértése elősegítené az erôteljesebb nemzeti részvételt

- Aktív szubszidiaritás kialakítása - tagállami részvétel tovább növelése

${ }^{30} \mathrm{COM} / 2016 / 0861$ JAVASLAT

31 ORSZÁGGYÜLÉS, 2020.

${ }^{32}$ RÁCZ, 2012.

${ }^{33}$ REPORT OF THE TASK FORCE ON SUBSIDIARITY, 2018. 
- A hatékonyság növelése érdekében új múködési minta kidolgozása a szubszidiaritás és az arányosság elveinek gyakorlati megvalósítására - ez az új múködési minta a már létező intézményrendszerre kell alapozzon és az eddigi tapasztalatokra kell építsen.

A munkacsoport 2019 márciusáig folytatja a tevékenységét - az eddig is egyre erôteljesebben érvényesülő szubszidiaritás tehát az uniós politika központjában áll és hatékonyságának további növelése várható az integrációtól. Igen röviden összefoglalva a feldolgozottakat, a szubszidiaritás elméletének megközelítőleg másfél évszázados fejlődése alatt általános, bármely tudományterületen megjelenő elvétől napjainkra az Európai Unió, mint regionális nemzetközi szervezet múködésének sajátjává és sajátosságává, fontos alapelvévé vált, ezáltal a mindenkori tagállamok jogrendszerének is meghatározó eleme. További fejlesztés tárgya és erôsítendő, múködési elv ugyan, azonban a gyakorlatban is jól láthatóan már jelenlegi szabályozása mellett is megjelenik és érvényesül.

\section{FELHASZNÁLT IRODALOM}

AMSZTERDAMI SZERZŐDÉS AZ EURÓPAI UNIÓRÓL SZÓLÓ SZERZŐDÉS, AZ EURÓPAI KÖZÖSSÉGEKET LÉTREHOZÓ SZERZŐDÉSEK ÉS EGYES KAPCSOLÓDÓ OKMÁNYOK MÓDOSÍTÁSÁRÓL (1997) A szubszidiaritás és az arányosság elveinek alkalmazásáról szóló jegyzőkönyv, C rész, 5-6. bekezdések, Elérhetô: http://www.europarl.europa.eu/topics/treaty/pdf/amst-en.pdf, (Letöltve: 2018.10.14)

AZ EuRÓPAi UNióRól SZÓló SZERZŐdÉs (MAASTRICHTI SZERZŐDÉS) (1992) Preambulum A cikk 2. bekezdés, Preambulum B cikk 2. bekezdés, 3b cikk 2. bekezdés, Elérhető: https://eurlex.europa.eu/legalcontent/EN/TXT/HTML/?uri=CELEX $: 11992 \mathrm{M} / \mathrm{TXT} \&$ from $=\mathrm{EN}$, (Letöltve: 2018.10 .14 )

AZ EURÓPAI UNIÓRÓl SZÓló SZERZŐdÉS (MAASTRICHTI SZERZŐDÉS) (1992) $5 . \quad c i k k$, Elérhető: https://eurlex.europa.eu/legalcontent/EN/TXT/HTML/?uri=CELEX $: 11992 \mathrm{M} / \mathrm{TXT} \&$ from $=\mathrm{EN}$, (Letöltve: 2018.10 .14 )

Bosnich A., DAvid (2010): The Principle of Subsidiarity, Religion and Liberti Vol.6. Nr. 4., https://acton.org/pub/religion-liberty/volume-6number-4/principle-subsidiarity, (Letöltve: 2018.10.14) 
CAMBRIDGE DICTIONARY (2019): Subsidiarity, Elérhető: https://dictionary.cambridge.org/dictionary/english/subsidiarity, (Letöltve: 2020.04.02)

COM/2013/0534 Javaslat a Tanács rendeletéről az Európai Ügyészség létrehozásáról, Elérhető: WEB/dossier/document/COM20130534.do, (Letöltve: 2018.10.16)

COM/2015/0450 Javaslat az Európai Parlament és a Tanács rendelete áthelyezési válságmechanizmus létrehozásáról, valamint az egy harmadik országbeli állampolgár vagy egy hontalan személy által a tagállamok egyikében benyújtott nemzetközi védelem iránti kérelem megvizsgálásáért felelős tagállam meghatározására vonatkozó feltételek és eljárási szabályok megállapításáról szóló, 2013. június 26-i 604/2013/EU európai parlamenti és tanácsi rendelet módosításáról, Elérhetô: http://www.ipex.eu/IPEXLWEB/dossier/document/COM20150450.do, (Letöltve: 2018.10.16)

COM/2017/0647 Javaslat az Európai Parlament és a Tanács rendelete az autóbusszal végzett személyszállítás nemzetközi piacához való hozzáférés közös szabályairól szóló 1073/2009/EK rendelet módosításáról, Elérhetô: $\quad$ http://www.ipex.eu/IPEXLWEB/dossier/document/COM20170647.do, (Letöltve: 2018.10.16)

COM/2016/0270 Javaslat az Európai Parlament és a Tanács rendelete egy harmadik országbeli állampolgár vagy egy hontalan személy által a tagállamok egyikében benyújtott nemzetközi védelem iránti kérelem megvizsgálásáért felelős tagállam meghatározására vonatkozó feltételek és eljárási szabályok megállapításáról (átdolgozás), Elérhető: http://www.ipex.eu/IPEXL-

WEB/dossier/document/COM20160270.do, (Letöltve: 2018.10.16)

COM/2016/0861 Javaslat az Európai Parlament és a Tanács rendelete a villamos energia belső piacáról, http://www.ipex.eu/IPEXLWEB/dossier/document/COM20160861.do, Elérhető: (Letöltve: 2018.10.16)

EGÉSzSÉGTUDOMÁNYI FOGALOMTÁR (2018): Szubszidiaritás, Elérhetô: https://fogalomtar.aeek.hu/index.php/Szubszidiarit\%C3\%A1s, (Letöltve: 2018.10.14)

EGYSÉGES EuRÓPAI OKMÁNY (1986) 130r. cikk 4. bekezdés, Elérhető: https://eur-lex.europa.eu/legalcontent/EN/TXT/PDF/?uri=CELEX:11986U/TXT\&from=EN, (Letöltve:2018.10.14) 
EUR-Lex (2015): A szubszidiaritás elve, Elérhető: https://eurlex.europa.eu/legal-content/HU/TXT/?uri=LEGISSUM\%3Aai0017, (Letöltve: 2018.10.15)

EUR-Lex (2018): Committee of the Regions, Elérhető: https://eurlex.europa.eu/summary/glossary/committee regions.html, (Letöltve: 2018.101.15)

European PARLIAMENT (2020): Factsheets on the European Union: The Principle of Subsidiarity, Elérhető: http://www.europarl.europa.eu/factsheets/en/sheet/7/the-principleof-subsidiarity, (Letöltve: 2020.04.02) European Council in Edinburgh (1992) - Conclusions of the Presidency (Part A - Subsidiarity) Elérhető: https://www.consilium.europa.eu/media/20492/1992 december edinburgh eng_pdf, (Letöltve: 2018.10.14)

FARKAS PÉTER (2014): A szubszidiaritás alapelve és gyakorlati alkalmazásának néhány területe, Kapocs, XIII. évfolyam, 4. szám, p. 66., http://www.ncsszi.hu/download.php?file id=1966,

(Letöltve: 2018.10.14)

LISSZABONI SZERZŐDÉS AZ EURÓPAI UNIÓRÓL SZÓLÓ SZERZŐDÉS ÉS AZ EURÓPAI KÖZÖSSÉGET LÉTREHOZÓ SZERZŐDÉS MÓDOSÍTÁSÁRÓL (2008) A szubszidiaritás és az arányosság elveinek alkalmazásáról szóló jegyzőkönyv, 7. cikk, Elérhető: https://eur-lex.europa.eu/legalcontent/EN/TXT/HTML/?uri=CELEX:12007L/TXT\&from=EN, (Letöltve: 2018.10.14)

MAgYAR KATOLIKUS LEXIKON (2019): Szubszidiaritás, Elérhető: http://lexikon.katolikus.hu/S/szubszidiarit $\% \mathrm{C} 3 \% \mathrm{~A} 1 \mathrm{~s}$.html, (Letöltve: 2020.04.02)

MERRIAM - WebSTER DiCTIONARY (2019): Subsidiarity, Elérhető: https://www.merriam-webster.com/dictionary/subsidiarity, (Letöltve: 2020.04.02)

ORSZÁGGYÜLÉS (2020): A szubszidiaritás elve érvényesülésének uniós és hazai szabályozása, Elérhető: http://www.parlament.hu/szubszidiaritasvizsgalat, (Letöltve: 2020.04.02)

RÁCZ RITA (2012): A szubszidiaritás-ellenőrzési mechanizmus a gyakorlatban: Mennyire és hogyan élnek jogosítványukkal a nemzeti parlamentek az uniós döntéshozatali eljárásokban?, University of Miskolc Collegium Doctorum, Elérhető: 


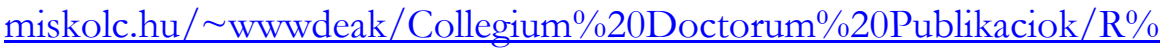
E1cz\%20Rita.pdf, (Letöltve: 2018.10.15)

REPORT OF THE TASK FORCE ON SUBSIDIARITY (2018): Proportionality and "Doing Less More Efficiently", Elérhető: https://ec.europa.eu/commission/sites/beta-political/files/report-taskforce-subsidiarity-proportionality-doing-less-moreefficiently 1.pdf?utm source $=$ mandiner\&utm medium $=$ link\&utm cam paign =mandiner 201810 , (Letöltve: 2018.10.15)

SCHILLING, THEODOR (1995): Subsidiarity as a Rule and a Principle, or: Taking Subsidiarity Seriously, The Jean Monet Center for International and Regional Economic Law and Justice, https://jeanmonnetprogram.org/archive/papers/95/9510ind.html, (Letöltve: 2018.10.14)

VARga Orsolya (2016): A szubszidiaritás elve, Civilek.hu Tudástár, Elérhető: $\quad$ https://www.civilek.hu/tudastar/a-szubszidiaritas-elve/, (Letöltve: 2018.10.14) 